\title{
Melanosis and quality attributes of chill stored farm raised whiteleg shrimp (Litopenaeus vannamei)
}

\author{
S. R. Senapati, G. Praveen Kumar, Chongtham Baru Singh, K. A. Martin Xavier, M. K. \\ Chouksey, B. B. Nayak and Amjad K. Balange*
}

Department of Post-Harvest Technology, ICAR-Central Institute of Fisheries Education, Mumbai-400061 (Maharashtra), INDIA

*Corresponding author. E-mail:amjadbalange@cife.edu.in

Received: March 17, 2016; Revised received: January 19, 2017; Accepted: February 26, 2017

\begin{abstract}
Loss of market value of shrimp is mainly due to the formation of black spot called melanosis. A study was conducted for 14 days to determine the extent of melanosis and quality changes during that period of freshly harvested whiteleg shrimp (Litopenaeus vannamei) under chilled storage $\left(2^{\circ} \mathrm{C}\right.$ ). Among quality parameters, total volatile basic nitrogen (TVB-N), thiobarbituric acid reactive substances (TBAR-S), were varied from $13.17 \mathrm{mg} \%$ to $44.50 \mathrm{mg}$ $\%$ and 0.04 to $2.57 \mathrm{mg}$ malondehaldehyde/kg of fat respectively whereas melanosis score and metric chroma (C) exhibited significant increases during chilled storage $(\mathrm{P}<0.05)$. There was a slight increase in moisture, crude fat and $\mathrm{pH}$ from $73.96 \%$ to $74.57 \%, 1.05 \%$ to $1.14 \%$ and 6.52 to 7.60 respectively at $14^{\text {th }}$ day of storage. Loss of protein from $22.51 \%$ to $21.28 \%$ may be due to decrease in available amino acids during chilled storage and total plate count (TPC) showed gradual increase of bacterial load up to $1.73^{*} 10^{7} \mathrm{log}$ CFU/g at the end of chilled storage. The sensory analysis by panellists indicated, the acceptability of whiteleg shrimp was up to 6 days in chilled condition and formation of black spot is one of the major parameter for rejection by the panellists.
\end{abstract}

Keywords: Litopenaeus vannamei, Melanosis, Quality, Sensory characteristics

\section{INTRODUCTION}

The global capture and culture production of whiteleg shrimp (Litopenaeus vannamei) is 10924 tonnes and 3668681 tonnes respectively in 2014 (FAO Fish Stat., 2016). It is an important aquaculture species having high market value in all over the world and leading farm-raised species in the western hemisphere, representing more than $99 \%$ of production. L. vannamei is mainly consumed in the North, Latin America, Europe and Asian countries. The market value of shrimp is generally based on the visual appearance of their body colour. The appearance of product and the resulting quality implications play a significant role in maintaining a high consumer acceptance. Shrimps are very perishable with short shelf life and susceptible to black spot formation called melanosis during post-mortem handling and storage. Melanosis starts in frozen and refrigerated crustaceans after a few hours of capture and it is brought on by the action of polyphenol oxidase, which oxidizes phenols to quinones. Polymerization of this quinones give rise a black pigment, which are not dangerous to human health, but affects the crustaceans appearance and loses its market value (Montero et al., 2001).

Apart from melanosis, quality of shrimp is affected due to several changes like lipid oxidation, protein denaturation during chilled storage (Imran et al., 2013). Colour, flavour, taste are also affected due to bacteriological activity during storage period (Sriket et al., 2007). $\mathrm{pH}$ is also one of the most important quality parameter during storage which is related with the growth of microbes in the sample. This is an important index for determining the quality of fish (Okeyo et al., 2009). The main reason of spoilage in fresh seafood is due to the activity of microorganisms which leads to undesirable flavours and odours. According to Qingzhu (2003), total viable count (TVC) is used as the acceptability index in standards, guidelines and specifications. Similarly, total volatile basic nitrogen (TVB-N) is an indicator of seafood freshness mainly due to spoilage bacteria (Huss, 1995).

Besides the protein and lipid fractions, deterioration in sensory quality, loss of nutritional value and changes in physico-chemical properties has been reported by Bennour et al., 1991, Nunes et al., 1992. Riaz et al. (1990) has reported about the chemical changes like lipid oxidation, volatile basic nitrogen in shrimp quality during frozen storage. Similarly, the shelf life of shrimp at variable temperature of frozen conditions has been studied by Tsironi et al. (2009). They selected colour, texture, $\mathrm{pH}$, microbial load, and T-VBN as the indices of quality for frozen shrimp. Specifically, the breakdown of fat and proteins are important stages of 
decomposition observed in fishery products which are kept either chilled or in frozen condition (Essien,1995 and Fatima et al., 1988).

As L. vannamei is one of the most important export item among shrimps, unfavourable colour change associated with melanosis on its surface and quality changes during that period has been of great concern to food processors. Based on this background, the aim of present investigation was to study the extent of melanosis on whiteleg shrimp (L. vannamei) as well as to monitor the physico-chemical, microbial and sensory properties during melanosis in chilled storage.

\section{MATERIALS AND METHODS}

Shrimp collection and preparation: Whiteleg shrimp (L. vannamei) with the count of 30-35 shrimps $/ \mathrm{kg}$ were purchased from a farm in Surat, India. The shrimp, freshly caught and completely free of additives, were kept in ice with a shrimp: ice ratio of 1:2 (w/w) and transported to the Department of PostHarvest Technology, ICAR-Central Institute of Fisheries Education, Mumbai within 3 hours. Upon arrival, shrimp were stored in a low temperature freezer (at $2^{\circ} \mathrm{C}$ ). Time zero was taken as the day of harvest. Physico-chemical, microbial, sensory and melanosis assessments were done in every alternative day up to14 days. Physico-chemical analysis: Moisture, crude protein, $\mathrm{pH}$, and ash contents were measured following standard method (AOAC, 2000). Differences in weight were recorded after drying the sample in hot air oven at 100 $\pm 5^{\circ} \mathrm{C}$ overnight to determine the moisture content. The crude protein content was measured by using the micro -kjeldahl method. Ten-gram samples were homogenized with $50 \mathrm{ml}$ distilled water in a homogenizer (Polytron system PT 2100, Kinematica, AG, Germany) for $30 \mathrm{~s}$ and $\mathrm{pH}$ value of fish homogenate was measured by a digital $\mathrm{pH}$ meter (Eutech tutor $\mathrm{pH} /{ }^{0} \mathrm{C}$ meter, Eutech Instruments, Singapore) standardized earlier by buffers at $\mathrm{pH} 4$ and 9 . Ashing was done by incineration in a muffle furnace at $550 \pm 50{ }^{\circ} \mathrm{C}$ until white ash was

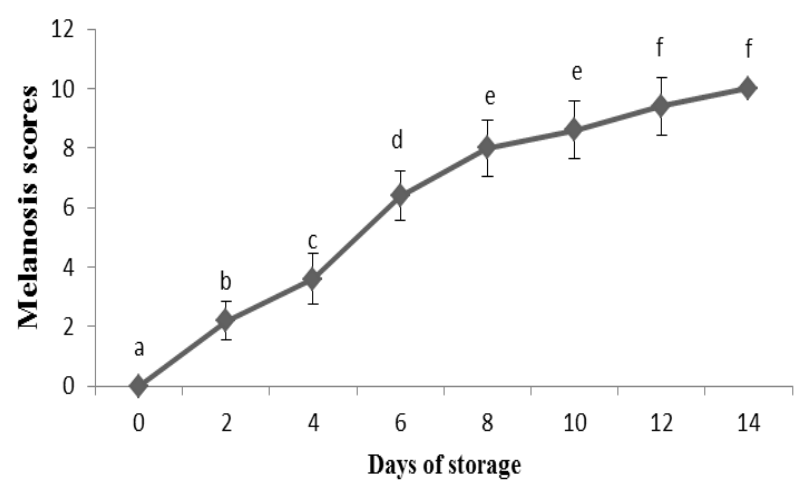

Fig. 1. Changes in melanosis scores of whiteleg shrimp (L. vannamei) during chilled storage.

Values are mean (SD), $n=3$, Different small letters in the barsare significantly different at $(\mathrm{p}<0.05)$ obtained. Ten percent trichloroacetic acid (TCA) extract was used to estimate total volatile basic nitrogen (TVB-N) by using Conway's micro-diffusion method (Conway, 1947) and expressed as mg \%. Crude fat was measured by Soxhlet extraction with diethyl ether. Thiobarbituric acid reactive substances (TBARS) were determined by the titrimetric method of Tarladgiset al. (1960) using thiobarbituric acid standard in $90 \%$ glacial acetic acid and expressed as mg malondehaldehyde/ $\mathrm{kg}$ of fat.

Determination of colour attributes: The colour measurements were carried out using the Hunter $L, a$, and $b$ scales, according to the method of Arfat and Benjakul, (2012) with slight modifications to evaluate the surface of shrimp samples. All colour determinations were carried out three times on different shrimp samples. The colorimeter (Hunter Lab scan XE, U.S.A.) employed was calibrated first with a black standard followed by a white standard to obtain the final setting, both placed centrally over the sample port. The dressed shrimp meat $(\sim 5 \mathrm{~g})$ was placed in an optically clear glass cup, which was placed on the port and covered with an opaque cup cover. The opaque cup cover whilst accommodating the shrimp sample contained, it excluded any external light interference. In this colour system, the L* variable represents lightness $\left(L^{*}=0\right.$ for black, $L^{*}=100$ for white). The $a^{*}$ scale represents the red/ green $\left(+\mathrm{a}^{*}\right.$ is red and $-\mathrm{a}^{*}$ is green) and the $b^{*}$ scale represents the yellow/ blue $\left(+b^{*}\right.$ is yellow and $-b^{*}$ is blue) (Hunterlab, 1996). The measurements were performed at room temperature. The parameters metric chroma $\left(\mathrm{C}=\left(\mathrm{a}^{* 2}+\mathrm{b}^{*^{2}}\right)^{0.5}\right)$ was calculated using $\mathrm{a}^{*}$ and $\mathrm{b}^{*}$ values. Chroma is expressed as saturation or intensity and clarity of the colour. Metric chroma describes the saturation as well as measure of vividness of colour (Senapati et al., 2016).

Sensory evaluation: Organoleptic quality such as shell colour, meat colour, odour, taste, flavour, freshness and overall acceptability of whiteleg shrimp was

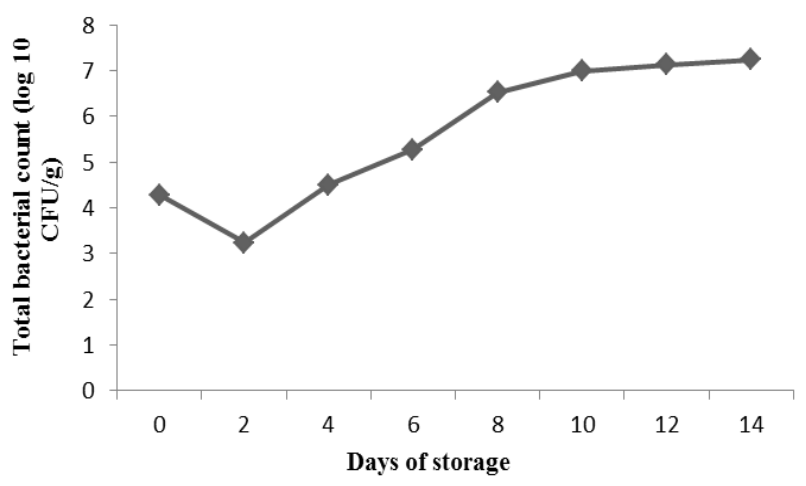

Fig. 2. Change in total bacterial counts of whiteleg shrimp (L. vannamei) during chilled storage.

Values are mean (SD), $\mathrm{n}=3$, Different small letters in the barsare significantly different at $(p<0.05)$ 
Table 1. Changes in proximate composition of whiteleg shrimp (L. vannamei) during chilled storage.

\begin{tabular}{lcccccccc}
\hline Paramaters & Fresh & $\mathbf{2}^{\text {nd }}$ Day & $\mathbf{4}^{\text {th }}$ Day & $\mathbf{6}^{\text {th }}$ Day & $\mathbf{8}^{\text {th }}$ Day & $\mathbf{1 0}^{\text {th }}$ Day & $\mathbf{1 2}^{\text {th }}$ Day & $\mathbf{1 4}^{\text {th }}$ Day \\
\hline Moisture (\%) & $73.96^{\mathrm{ab}} \pm 0.16$ & $74.65^{\mathrm{c}} \pm 0.32$ & $73.58^{\mathrm{a}} \pm 0.39$ & $73.66^{\mathrm{a}} \pm 0.19$ & $74.33^{\mathrm{bc}} \pm 0.65$ & $74.32^{\mathrm{bc}} \pm 0.59$ & $74.30^{\mathrm{bc}} \pm 0.23$ & $74.57^{\mathrm{bc}} \pm 0.22$ \\
Crude protein (\%) & $22.51^{\mathrm{bc}} \pm 0.13$ & $22.04^{\mathrm{abc}} \pm 0.08$ & $22.87^{\mathrm{c}} \pm 0.51$ & $21.93^{\mathrm{ab}} \pm 0.65$ & $21.38^{\mathrm{a}} \pm 0.85$ & $21.81^{\mathrm{ab}} \pm 0.33$ & $21.85^{\mathrm{ab}} \pm 0.35$ & $21.28^{\mathrm{a}} \pm 0.55$ \\
Crude fat (\%) & $1.05^{\mathrm{a}} \pm 0.07$ & $1.07^{\mathrm{a}} \pm 0.10$ & $1.13^{\mathrm{a}} \pm 0.16$ & $1.11^{\mathrm{a}} \pm 0.14$ & $1.14^{\mathrm{a}} \pm 0.10$ & $1.17^{\mathrm{a}} \pm 0.12$ & $1.20^{\mathrm{a}} \pm 0.09$ & $1.14^{\mathrm{a}} \pm 0.22$ \\
Ash (\%) & $1.96^{\mathrm{b}} \pm 0.10$ & $1.99^{\mathrm{b}} \pm 0.09$ & $1.90^{\mathrm{b}} \pm 0.05$ & $1.80^{\mathrm{b}} \pm 0.07$ & $1.54^{\mathrm{a}} \pm 0.09$ & $1.53^{\mathrm{a}} \pm 0.21$ & $1.49^{\mathrm{a}} \pm 0.27$ & $1.38^{\mathrm{a}} \pm 0.07$ \\
\hline
\end{tabular}

Values are mean $(\mathrm{SD}), \mathrm{n}=3$, Means on the same row with different superscripts are significantly different at $(\mathrm{p}<0.05)$

Table 2. Changes in TVB-N, TBAR-S and pH of whiteleg shrimp (L. vannamei) during chilled storage.

\begin{tabular}{|c|c|c|c|c|c|c|c|c|}
\hline Paramaters & Fresh & $2^{\text {nd }}$ Day & $4^{\text {th }}$ Day & $6^{\text {th }}$ Day & $\mathbf{8}^{\text {th }}$ Day & $10^{\text {th }}$ Day & $12^{\text {th }}$ Day & $\begin{array}{l}14^{\text {th }} \\
\text { Day }\end{array}$ \\
\hline TVB-N (mg \%) & $13.17 \pm 0.34^{\mathrm{a}}$ & $14.10 \pm 0.64^{\mathrm{a}}$ & $16.68 \pm 0.17^{b}$ & $18.51 \pm 0.31^{\mathrm{c}}$ & $26.13 \pm 1.02^{\mathrm{d}}$ & $30.53 \pm 0.47^{\mathrm{e}}$ & $36.91 \pm 0.90^{\mathrm{f}}$ & $44.50 \pm 0.43^{\mathrm{g}}$ \\
\hline $\begin{array}{l}\text { TBAR-S } \quad(\mathrm{mg} \\
\text { malondehaldehyde } \\
\text { of fat }\end{array}$ & $0.04 \pm 0.01^{\mathrm{a}}$ & $0.15 \pm 0.05^{\mathrm{b}}$ & $0.47 \pm 0.03^{\mathrm{c}}$ & $0.93 \pm 0.01^{\mathrm{d}}$ & $1.24 \pm 0.04^{\mathrm{e}}$ & $1.40 \pm 0.01^{\mathrm{f}}$ & $2.18 \pm 0.05^{\mathrm{g}}$ & $2.57 \pm 0.04^{\mathrm{h}}$ \\
\hline $\mathrm{pH}$ & $6.52 \pm 0.08^{\mathrm{a}}$ & $6.87 \pm 0.15^{\mathrm{b}}$ & $7.08 \pm 0.17^{\mathrm{bc}}$ & $7.18 \pm 0.03^{\mathrm{cd}}$ & $7.40 \pm 0.10^{\mathrm{de}}$ & $7.47 \pm 0.06^{\mathrm{e}}$ & $7.40 \pm 0.30^{\mathrm{de}}$ & $7.60 \pm 0.10^{\mathrm{e}}$ \\
\hline
\end{tabular}

Values are mean (SD), $\mathrm{n}=3$, Means on the same row with different superscripts are significantly different at $(\mathrm{p}<0.05)$

evaluated throughout the storage time. The shrimps were peeled, cooked for 5 minutes and given only for taste and other parameters were evaluated by unpeeled samples in another plate with random coding. Panellists were acquainted with shrimp consumption and had no allergies to shrimp. All panellists $(n=10)$ were asked to judge and give the overall score on a 9 point Hedonic scale where $9=$ like extremely; $7=$ like moderately; 5 = neither like or nor dislike; 3 = dislike moderately; 1 = dislike extremely. (Nirmal et al. 2011)

Melanosis Assessment: Melanosis or blackening of whiteleg shrimp was evaluated through visual inspection by ten trained panellists using 10-point scoring test (Montero et al., 2001). Samples (10 shrimps) were selected randomly and evaluated for melanosis score, throughout the storage time. Panellists were asked to give the melanosis score $(0-10)$, where $0=$ absent; $2=$ slight (up to $20 \%$ of shrimps' surface affected); $4=$ moderate $(20-40 \%$ of shrimps' surface affected); $6=$ notable $(40-60 \%$ of shrimps' surface affected); $8=$ severe $(60-80 \%$ of shrimps' surface affected); $10=$ extremely heavy $(80-100 \%$ of shrimps' surface affected).

Microbiological analysis: Total plate count (TPC) analysis was carried out as per the spreadplate technique. Whole shrimp sample $(10 \mathrm{~g})$ placed in sterileplastic stomacher bag was homogenised $(60 \mathrm{~s})$ with $90 \mathrm{~mL}$ of thephysiological saline $(0.85 \%)$ using a BagMixer. A serial 10-fold dilution of thehomogenate was prepared and $0.1 \mathrm{~mL}$ aliquots were pipetted intosterile petri dishes. About 10-15 mL aliquot of molten autoclaved Plate Count Agar (PCA) (Hi-media, India) was poured into the petri dish and gently swirled 2-3 times. Plates were incubated for 48 hours at $37{ }^{\circ} \mathrm{C}$ and counted. The microbiological analysis was conducted in duplicates and the results were expressed as logarithm of colony forming units (log CFU/g) of shrimp muscle (Arashisara et al., 2004; Sallam, 2007).

Statistical analysis: Analysis of variance (one way -
ANOVA) was performed to determine the differences between storage periods of $L$. vannamei followed by Duncan's multiple range tests (for Post hoc analyses) to compare the means $(\mathrm{p}<0.05)$ of parameters analysed during the experiment. The results are presented as means \pm SD. All statistical analyses were performed using Statistical Package for Social Sciences (SPSS, version 16.0 for windows).

\section{RESULTS AND DISCUSSION}

Changes in proximate composition of whiteleg shrimp during chilled storage: Changes in proximate composition of $L$. vannamei are given in Table 1 . The moisture, protein, fat and ash of fresh shrimp were $73.96 \%, 22.51 \%, 1.05 \%$ and $1.96 \%$ respectively.

The moisture content varied between $73.96 \%$ and $74.57 \%$. On the $2^{\text {nd }}$ day, the slight increase in moisture content $(74.65 \%)$ might be due to the sudden temperature difference in the low temperature freezer comparing with room temperature. Thereafter, there was a slight decrease in moisture content on $4^{\text {th }}$ and $6^{\text {th }}$ day of sampling. This decrease in moisture content might be due to sublimation of surface water of the meat in the refrigerator. However, no significant difference $(p>0.05)$ was observed in the moisture content in later stages. It can be compared with the moisture differences reported by Huidobro et al. (2002) during icedstored deep water pink shrimp which were processed on-board a ship. The ash content of species is an indication of mineral concentration in the organisms (Anon, 1995). The ash content was ranged from 1.96 $\%$ to $1.38 \%$. There was a slight reduction in crude protein content of whiteleg shrimp from $22.51 \%$ to $21.28 \%$. This decrease might be related to the increased microbial growth resulted from higher water activity (aw) and enzymatic autolysis at low temperature (Kandeepan and Biswas, 2007). Another reason might be due to the loss of available amino acids during storage as reported by Fatima et al.(1988). Ko- 
S. R. Senapati et al. / J. Appl. \& Nat. Sci. 9 (1): 626 - 631 (2017)

Table 3. Colour changes in muscles of whiteleg shrimp (L. vannamei ) during chilled storage.

\begin{tabular}{lllllllll}
\hline Parameters & Fresh & $\mathbf{2}^{\text {nd }}$ Day & $\mathbf{4}^{\text {th }}$ Day & $\mathbf{6}^{\text {th }}$ Day & $\mathbf{8}^{\text {th }}$ Day & $\mathbf{1 0}^{\text {th }}$ Day & $\mathbf{1 2}^{\text {th }}$ Day & $\mathbf{1 4}^{\text {th }}$ Day \\
\hline $\mathrm{L}^{*}$ & $31.51^{\mathrm{cd}} \pm 1.06$ & $32.45^{\mathrm{d}} \pm 0.91$ & $31.56^{\mathrm{cd}} \pm 0.8932 .59^{\mathrm{d}} \pm 1.88$ & $41.14^{\mathrm{e}} \pm 1.02$ & $30.29^{\mathrm{bc}} \pm 0.78$ & $29.12^{\mathrm{ab}} \pm 1.13$ & $27.61^{\mathrm{a}} \pm 1.13$ \\
$\mathrm{a}^{*}$ & $-0.45^{\mathrm{c}} \pm 0.12$ & $-0.53^{\mathrm{bc}} \pm 0.08$ & $-0.54^{\mathrm{bc}} \pm 0.11$ & $-0.79^{\mathrm{ab}} \pm 0.10$ & $-0.66^{\mathrm{abc}} \pm 0.13$ & $-0.80^{\mathrm{ab}} \pm 0.09$ & $-0.92^{\mathrm{a}} \pm 0.26$ & $-0.85^{\mathrm{a}} \pm 0.22$ \\
$\mathrm{~b}^{*}$ & $2.71^{\mathrm{a}} \pm 0.55$ & $3.15^{\mathrm{a}} \pm 0.60$ & $3.38^{\mathrm{ab}} \pm 0.46$ & $4.48^{\mathrm{b}} \pm 0.66$ & $5.92^{\mathrm{c}} \pm 0.82$ & $8.12^{\mathrm{d}} \pm 0.91$ & $8.48^{\mathrm{d}} \pm 0.68$ & $8.89^{\mathrm{d}} \pm 0.80$ \\
$\mathrm{C}$ & $2.75^{\mathrm{a}} \pm 0.55$ & $3.19^{\mathrm{a}} \pm 0.60$ & $3.42^{\mathrm{ab}} \pm 0.46$ & $4.55^{\mathrm{b}} \pm 0.65$ & $5.96^{\mathrm{c}} \pm 0.80$ & $8.16^{\mathrm{d}} \pm 0.91$ & $8.54^{\mathrm{d}} \pm 0.65$ & $8.93^{\mathrm{d}} \pm 0.78$ \\
\hline
\end{tabular}

$L^{*}$ : Lightness, $a^{*}$ : Redness, $b^{*}$ : Yellowness, C: Metric chroma, Values are mean $(\mathrm{SD}), \mathrm{n}=3$, Means on the same row with different superscripts are significantly different at $(\mathrm{p}<0.05)$.

Table 4. Sensory evaluation of whiteleg shrimp (L. vannamei) during chilled storage.

\begin{tabular}{lcccccccc}
\hline $\begin{array}{l}\text { Sensory } \\
\text { parameters }\end{array}$ & Fresh $^{2}$ & $\mathbf{2}^{\text {nd }}$ Day & $\mathbf{4}^{\text {th }}$ Day & $\mathbf{6}^{\text {th }}$ Day & $\mathbf{8}^{\text {th }}$ Day & $\mathbf{1 0}^{\text {th }}$ Day & $\mathbf{1 2}^{\text {th }}$ Day & $\mathbf{1 4}^{\text {th }}$ Day \\
Shell colour & $9.10^{\mathrm{f}} \pm 0.21$ & $8.95^{\mathrm{f}} \pm 0.16$ & $7.90^{\mathrm{e}} \pm 0.57$ & $5.20^{\mathrm{d}} \pm 0.42$ & $3.50^{\mathrm{c}} \pm 0.53$ & $1.70^{\mathrm{b}} \pm 0.48$ & $1.40^{\mathrm{ab}} \pm 0.52$ & $1.10^{\mathrm{a}} \pm 0.32$ \\
Meat colour & $9.10^{\mathrm{f}} \pm 0.32$ & $8.75^{\mathrm{f}} \pm 0.26$ & $7.90^{\mathrm{e}} \pm 0.66$ & $6.45^{\mathrm{d}} \pm 0.76$ & $4.40^{\mathrm{c}} \pm 0.52$ & $3.00^{\mathrm{b}} \pm 1.05$ & $1.40^{\mathrm{a}} \pm 0.52$ & $1.40^{\mathrm{a}} \pm 0.52$ \\
Odour & $9.10^{\mathrm{f}} \pm 0.21$ & $8.70^{\mathrm{f}} \pm 0.26$ & $8.00^{\mathrm{e}} \pm 0.41$ & $6.70^{\mathrm{d}} \pm 0.48$ & $3.50^{\mathrm{c}} \pm 0.53$ & $3.30^{\mathrm{bc}} \pm 0.48$ & $2.90^{\mathrm{b}} \pm 0.57$ & $2.00^{\mathrm{a}} \pm 0.67$ \\
Taste & $9.15^{\mathrm{f}} \pm 0.24$ & $9.10^{\mathrm{f}} \pm 0.39$ & $8.40^{\mathrm{e}} \pm 0.39$ & $6.70^{\mathrm{d}} \pm 0.54$ & $4.60^{\mathrm{c}} \pm 0.52$ & $4.30^{\mathrm{c}} \pm 0.82$ & $3.20^{\mathrm{b}} \pm 0.42$ & $2.70^{\mathrm{a}} \pm 0.67$ \\
Flavour & $9.10^{\mathrm{f}} \pm 0.21$ & $8.90^{\mathrm{f}} \pm 0.46$ & $8.40^{\mathrm{e}} \pm 0.47$ & $6.45^{\mathrm{d}} \pm 0.50$ & $3.30^{\mathrm{c}} \pm 0.48$ & $3.30^{\mathrm{c}} \pm 0.53$ & $2.60^{\mathrm{b}} \pm 0.52$ & $1.50^{\mathrm{a}} \pm 0.53$ \\
Freshness & $9.05^{\mathrm{e}} \pm 0.16$ & $8.80^{\mathrm{de}} \pm 0.35$ & $8.45^{\mathrm{d}} \pm 0.55$ & $6.50^{\mathrm{c}} \pm 0.53$ & $3.20^{\mathrm{b}} \pm 0.42$ & $3.00^{\mathrm{b}} \pm 0.82$ & $1.50^{\mathrm{a}} \pm 0.53$ & $1.30^{\mathrm{a}} \pm 0.48$ \\
Overall & $9.15^{\mathrm{f}} \pm 0.24$ & $8.95^{\mathrm{f}} \pm 0.28$ & $7.80^{\mathrm{e}} \pm 0.42$ & $6.60^{\mathrm{d}} \pm 0.39$ & $3.60^{\mathrm{c}} \pm 0.52$ & $3.25^{\mathrm{c}} \pm 0.54$ & $2.40^{\mathrm{b}} \pm 0.46$ & $1.85^{\mathrm{a}} \pm 0.24$ \\
acceptability & & & & & & &
\end{tabular}

Values are mean (SD), $\mathrm{n}=3$, Means on the same row with different superscripts are significantly different at $(\mathrm{p}<0.05)$

lodjiejska et al. (1987) observed a remarkable rate of denaturation and autolysis of fish protein while working on biochemical changes in fish muscle during low temperature storage. The present study showed the slight increase of crude fat during the whole storage. However, the values were not statistically significant ( $p>0.05)$ and ranged between $1.05 \%$ and $1.20 \%$.

Changes in TVB-N, TBAR-S and pH: Changes in TVB-N value of whiteleg shrimp during chilled storage up to 14 days are shown in Table 2. The TVB-N value generally indicates conversion of proteins and non-proteins to ammonical nitrogen and amines, usually having high $\mathrm{pH}$. In fresh L. vannamei, TVB-N content was $13.17 \mathrm{mg} \%$, which was below the maximum limit of acceptance of $30 \mathrm{mg} / 100 \mathrm{~g}$ suggested by Food safety and standards authority of India (FSSAI). Within the first two days of storage no differences in TVB-N content of whiteleg shrimp $(p>0.05)$ and $4^{\text {th }}$ day onwards there was a significant increase $(p<0.05)$ in TVB-N values. According to Gopakumar (2002), TVB-N value recommended for good quality fish is less than 35 - $40 \mathrm{mg} \mathrm{N} / 100 \mathrm{~g}$. In the present study, after $10^{\text {th }}$ day the values exceeded the acceptable limit. The $\mathrm{pH}$ is an important index for determining the quality of fish (Okeyo et al. 2009). Changes in $\mathrm{pH}$ of whiteleg shrimp during chilled storage up to 14 days are depicted in Table 2. Fresh whiteleg shrimp had a $\mathrm{pH}$ of 6.52 . As the storage time increased, the $\mathrm{pH}$ increased significantly $(\mathrm{P}<0.05)$ and reached at 7.60 by $14^{\text {th }}$ day. This increase might be caused by the growth of spoilage bacteria leading to the accumulation of alkaline components (e.g., ammonia and trimethylamine) (Chaijan et al., 2005).

Fat oxidation in the fish muscle in terms of thiobarbituric acid (TBA) value during the course of chilled storage of whiteleg shrimp are presented in Table 2 . TBA value is an index of oxidative rancidity in the fish muscle (Gopakumar, 2002). The present study shows significant increment $(\mathrm{p}<0.05)$ of TBA value due to the formation of fatty acid hydro-peroxides during the course of storage and the value increased from $0.04\left(0^{\text {th }}\right.$ day) to $2.57 \mathrm{mg}$ malondehaldehyde $/ \mathrm{kg}$ of fat $\left(14^{\text {th }}\right.$ day). For a seafood product to be acceptable for consumption, a recommended TBA value is less than 2 (Gopakumar, 2002). The L. vannamei exceeded the acceptable limit on 12th day of storage in this study.

Instrumental colour analysis: Colour is one of the essential parameters which determine the quality attributes of food (Du and Sun, 2011). Instrumental colour measurements of whiteleg shrimp are presented in the Table 3. This instrumental analysis is normally used as supportive information to determine the degree of quality of whiteleg shrimp in melanosis and sensory analysis. Present study assessed the colour attributes with respect to metric chroma under chilled storage. During chilled storage, up to day $6^{\text {th }}$, the lightness remained unchanged $(\mathrm{P}>0.05)$ and would increase up to a peak on $8^{\text {th }}$ day (41.14), later stage there was a decline till the end of storage $(\mathrm{P}<0.05)$. This result seems to be in agreement with the previous observations of Okpala et al. (2014) who reported increases in metric chroma of untreated Pacific white shrimp during iced storage. There was no significant difference observed in $\mathrm{a}^{*}$ value of shrimp during chilled storage $(\mathrm{P}>0.05)$. Concerning yellowness $\left(b^{*}\right)$ value and particularly during the initial 4 days of storage, there was no significant difference observed $(\mathrm{P}>0.05)$ whereas after $4^{\text {th }}$ day, the $\mathrm{b}^{*}$ significantly increased up to a peak $(8.93)$ by day 14 $(\mathrm{P}<0.05)$. The significant increase in yellowness $\left(\mathrm{b}^{*}\right)$ was observed by Bak et al.(1999) for the untreated 
shrimp with iced storage, where a colour shift was observed from somewhat red to a more yellow appearance. This might have occurred due to fair breakdown of astaxanthin, which might attribute to high pressure exerted by presence of oxygen.

Melanosis and sensory analysis: Melanosis and sensory characteristics of the white leg shrimp during chilled storage are shown in Figure 1 and Table 4 respectively. Shell colour, meat colour, odour, taste, flavour, freshness and overall acceptability of whiteleg shrimp were evaluated during the storage period. As storage time increased, the sensory scores given by panellists on 9 point hedonic scale for all sensory parameters were decreased significantly $(\mathrm{P}<0.05)$. Similarly, the study of melanosis scores by visual inspection were exhibited significant increase $(\mathrm{P}<0.05)$ after $1^{\text {st }}$ day of storage. The higher scores for melanosis were in agreement with the low colour values of shell and meat after $6^{\text {th }}$ days of storage. At this point, the shrimp surface was severely affected by black spot ( 60 $\%-80 \%$ ) and the product was disliked by the panellists. This result can be related to the Alvarez et al. (2005), where the black spot increased after 1 day in untreated tiger prawns (Marsupenaeus japonicus) during chilled storage.

Microbiological analysis: Figure 2 shows the total bacterial counts of whiteleg shrimp during chilled storage of 14 days. The initial count was $1.89 * 10^{4} \log$ $\mathrm{CFU} / \mathrm{g}$ and decreased to $1.73 * 10^{3} \log \mathrm{CFU} / \mathrm{g}$ on $2^{\text {nd }}$ day and later stage it was increased to a value of $1.73 * 10^{7} \log \mathrm{CFU} / \mathrm{g}$ at the end of chilled storage. But actually, microbial load was enlarged after $6^{\text {th }}$ day of storage and this result is equal to Lopez-Caballero et al., 2006. The decrease of microflora in earlier stage of storage might be due to the effect of low temperature (Zeng et al., 2005) and the later increase might be due to the tolerance to cold conditions of those microorganisms up to a certain limit in shrimp (Nirmal et al., 2009). This finding is similar to Panchavarnam et al. (2003) in which the initial counts increased to a value of $5.2 * 10^{7}$ after 14 days of storage of whole rohu in ice.

\section{Conclusion}

The present study concluded that the degrading changes in biochemical and microbial composition had increased with period which had a direct effect on shelf life and market value of $L$. vannamei. The melanosis had started from $6^{\text {th }}$ day onwards. But TVB-N as a quality index, shrimp is acceptable till $10^{\text {th }}$ day. By correlating the results of colour, sensory scores and melanosis index, it was indicated that L. vannamei can be stored till 6 days in chilled storage without any black discoloration. However, the information created by this experiment provides the baseline for preservative treatments applied to whiteleg shrimp to prevent melanosis.

\section{ACKNOWLEDGEMENTS}

The University Grant Commission (UGC) sponsored national fellowship received by the first author is gratefully acknowledged. Authors also thank Director, Central Institute of Fisheries Education, for providing necessary facilities.

\section{REFERENCES}

Alvarez, O. M., Caballero, M. E. L., Montero, P. and Gómez -Guillén, M. C. (2005). A 4-hexylresorcinol-based formulation to prevent melanosis and microbial growth in chilled tiger prawns (Marsupenaeus japonicus) from aquaculture. Journal of Food Science, 70, M415-M422.

Anon, A. (1995). Quality assurance and monitoring system manual on export of fresh, frozen processed fish and fishery products. Export inspection council of India, Manual of quality assurance of sea foods, Ministry of commerce.

AOAC (2000). Official Methods of Analysis. 17th edn., Association of Official Analytical Chemists, Washington, DC, USA.

Arashisara, S., Hisara, O., Kayab M. and Yanik, T. (2004). Effects of modified atmosphere and vacuum packaging on microbiological and chemical properties of rainbow trout fillets. Food Microbiology, 97, 209-214.

Arfat, Y. and Benjakul, S. (2012). Gelling characteristics of surimi from yellow stripe trevally (Selaroides leptolepis). International Aquatic Research, 4: 1-3.

Bak, L. S., Andersen, A. B., Andersen, E. M. and Bertelsen, G. (1999). Effect of modified atmosphere packaging on oxidative changes in frozen stored cold water shrimp (Pandalus borealis). Food Chemistry, 64: 169-175.

Bennour, M., El Marrakchi, A., Bouchriti, N., Hamama, A. and El Ouadaa M. (1991). Chemical and microbiological assessments of mackerel (Scomber scombrus) stored in ice. Journal of Food Protection, 54: 789-792.

Chaijan, M., Benjakul, S., Visessanguan, W. and Faustman, C. (2005). Changes of pigments and colour in sardine (Sardinella gibbosa) and mackerel (Rastrelligerkanagurta) muscle during iced storage. Food Chemestry, 93: 607-617.

Conway, E. J. (1947). Microdiffusion analysis and volumetric error. $4^{\text {th }} \mathrm{ed}$. Van Nostrad Co Inc. New York, 245.

Du, C. J. and Sun, D. W. (2011). Retrospective shading correlation of confocal laser scanning microscopy beef images for three dimensional visualisation. Food and Bioprocess Technology, 2:167-176

Essien, E. U. (1995). Lipid content and fatty acid profiles of some lesser known nigerian foods. Journal of food biochemistry, 19: 153-159

FAO, FishStat. (2016). The state of World Fisheries and Aquaculture, 2016. Food and Agriculture Organization, Rome, Italy.

Fatima, R., Khan, M. A. and Qadri, R. B. (1988). Shelf-life of shrimp (Penaeus merguiensis) stored in ice $\left(0^{\circ} \mathrm{C}\right)$ and partially frozen $\left(-3^{\circ} \mathrm{C}\right)$. Journal of the Science of Food and Agriculture, 42: 235-247

Gopakumar, K. (2002). Post mortem changes in fish and quality assessment. Text book of fish processing technology, Indian Council of Agricultural Research, New Delhi, India, 31-37. 
Huidobro, A., Lopez-Caballero, M.E. and Mendes, R. (2002). Onboard processing of deepwater pink shrimp (Parapenaeus longirostris) with liquid ice:effect on quality. European Food Research and Technology, 214: 469-475

Hunterlab. (1996). CIE L*a*b* color scale. Applications Note. http://www.hunterlab.com/application-notes.html. 314 acessed 20 November, 2013.

Huss, H. H. (1995). Quality and quality changes in fresh fish. Food and Agriculture Organization of the United Nations (FAO), Rome. FAO Fisheries Technical Paper.

Imran, A., Chawalit, J. and Somrote, K. (2013). Characterization of quality degradation during chilled shrimp (Litopenaeus vannamei) supply chain. International Food Research Journal, 20:1833-1842

Kandeepan, G. and Biswas S. (2007). Effect of low temperature preservation on quality and shelf life of buffalo meat. American Journal of Food Technology, 2: 126135

Kolodjiejska, I., Sikorski, Z. E. and Sandowska, M. (1987). Texture of cooked mantle of squid illexargentius as influenced by specimen characteristics and treatments. Journal Food Science, 52: 932-935

Lopez-Caballero, M.E., Martinez-Alvarez, O., GomezGuillen, M.D. and Montero, P. (2007). Quality of thawed deep water pink shrimp (Parapenaeus longirostris) treated with melanosis-inhibiting formulations during chilled storage. International Journal of Food Science and Technology, 42:1029-1038

Montero, P., Lopez-Caballero, M. E. and Perez-Mateos, M. (2001). The effect of inhibitors and high pressure treatment to prevent melanosis and microbial growth on chilled prawns (Penaeus japonicus). Journal of Food Science, 66:1201-1206

Nirmal, N. P. and Benjakul, S. (2009). Effect of ferulic acid on inhibition of polyphenoloxidase and quality changes of Pacific white shrimp (Litopenaeus vannamei) during iced storage. Food Chemistry, 116: 323-331

Nirmal, N. P. and Benjakul, S. (2011). Use of tea extracts for inhibition of polyphenoloxidase and retardation of quality loss of Pacific white shrimp during iced storage. LWT-food science and technology, 44: 924-932

Nunes, M., Batista, I. and Morao de Campos R. (1992). Physical, chemical and sensory analysis of sardine (Sardina pilchardus) stored in ice. Journal of the Science of Food and Agriculture, 59: 37-43

Okeyo, G. O., Lokuruka, N. I. and Matofari, J. W. (2009).
Nutritional composition and shelf life of the lake Victoria Nile perch (Lates niloticus) stored in ice. African Journal of Food, Agriculture, Nutrition and Development. 9: 3-6

Okpala, C.O.R., Choo, W.S. and Dykes, G.A. (2014). Quality and shelf life assessment of Pacific white shrimp (Litopenaeus vannamei) freshly harvested and stored on ice. LWT-Food Science and Technology, 55: 110-116

Qingzhu, Z. (2003). Quality indicators of Northern shrimp (Pandalus borealis) stored under different cooling conditions. The United Nations University. Tokyo, Japan: UNU-Fisheries Training Programme.

Riaz, M. and Qadri, R. B. (1990). Time-temperature tolerance of frozen shrimp 2. Biochemical and microbiological changes during storage of frozen glazed shrimps. Tropical Science, 30: 343-356

Panchavarnam, S., Manisha, K., Basu, S., Warrier, S. B. and Venugopal, V. (2003). Shelf life extension of whole and steaks of rohu (Labeo rohita) by gamma irradiation. Fishery Technology, 40: 36-41

Sallam, K. I. (2007). Antimicrobial and antioxidant effects of sodium acetate, sodium lactate, and sodium citrate in refrigerated sliced salmon. Food Control, 18: 566-575

Senapati, S. R., Xavier, K. A. M, Nayak, B. B. and Balange, A. K. (2016). Quality evaluation of edible fish flour prepared from indian oil sardine (Sardinella Longiceps). Journal of Food Processing and Preservation, doi:10.1111/jfpp.12982.

Sriket, C., Benjakul, S., Visessanguan, W. And Kijroongrojana, K. (2007). Comparative studies on chemical composition and thermal properties of black tiger shrimp (Penaeus monodon) and white shrimp (Penaeus vannamei) meats. Food chemistry, 103 (4): 1199-1207

Tarladgis, B. G., Watts, B. M. and Yonathan, M. (1960). Distillation method for the determination of malonaldehyde in rancid foods. Journal of the American Oil Chemists' Society, 37: 44-48

Tsironi, T., Dermesonlouoglou, E., Giannakourou, M. and Taoukis, P. (2009). Shelf life modelling of frozen shrimp at variable temperature conditions. LWT - Food Science and Technology, 42: 664-671

Zeng, Q. Z., Thorarinsdottir, K. A. and Olafsdottir, G. (2005). Quality changes of shrimp (Pandalus borealis) stored under different cooling conditions. Journal of Food Science, 70: 459-466 